DOI https://doi.org/10.30525/978-9934-571-83-1-15

\title{
ECONOMIC AND SOCIAL SYSTEMS OF SOCIETY AS ELEMENTS OF SOCIAL STRUCTURE: CONCEPT, OBJECTIVES, TRENDS
}

\author{
Nalyvaiko O. I., Chepik-Tregubenko O. S.
}

\section{INTRODUCTION}

The acquisition of independence by Ukraine, the adoption of a new Constitution and provisions of regulations which itemize it, other socially important events have become the basis for the beginning of the formation of a modern democratic social structure of Ukraine. At the same time, there has risen the question about the functioning of the social structure in modern conditions the development of civil society, the new details of its principles, the modernization of elements, the formation of the openness of Ukrainian society and state to the world community, interaction with international governmental and non-governmental organizations, the recent launch of the decentralization process power. Even more issues have risen in the field of the existing social structure after the aggravation of political, socio-economic situations, crises in the spiritual and cultural sphere, imbalances in the complex system of interaction between civil society institutions and their communication with public authorities.

Today, Ukrainian society needs to create such a system of social relations in each sphere that would ensure the stability and effectiveness of the interaction of the public within the existing social structure. The democratic modification of the social structure and the further formation of civil society in Ukraine have a single vectorial direction.

Having declared the democratic vector of development and striving to enter the world community as an equal partner, Ukraine must meet the high demands of the present in both political, and social and economic aspects. Despite the powerful domestic human, economic, humanitarian and cultural potential, the Ukrainian state failed to realize its obvious advantages, to create a social and economic theory of development that would correlate with the present reality.

The formation of an open society in our country coincides with the development of the economic system of society. Contrary to the complexities and contradictions of the transition period, Ukraine is slowly strengthening as a rule of law, accelerating its integration into the world economic space. However, the processes associated with globalization predetermine the complexity of the task with regard to the previous stage. The problem of developing the economic system of society is one of the key and most theoretically significant for modern 
legal science and the development of civil society and the formation of a legal, social state in Ukraine.

The study of this problem has not only theoretical, but also important practical importance for the effective development of all spheres of society.

Some of the problematic issues of the formation of the economic system were studied in the writings of such scholars as O. Borysova, O. Bieliaieva, I. Grabynskyi, Z. Zalogy, V. Iokhina, M. Krupky, B. Kulchytskyi, R. Kuchukova, S. Liubymtseva, O. Mamontova, I. Myhasiuka, S. Mochernyi, L. Nalyvaiko, P. Ostroverha, S. Panchyshyna, S. Pogorielova, V. Popova, D. Potieieva, S. Reverchuk, D. Stechenko, O. Tyshchenko, V. Fomishchena, T. Shkliar and other scientists. However, the rapid pace of world economic development and the need to integrate Ukraine into these processes in order to effectively develop the modern social system require new scientific research in this field, in particular from the standpoint of science in the theory of state and law.

A number of issues in the subject are debatable. This indicates that the chosen problem is characterized by high relevance. At the same time, it should be noted that many foreign countries have accumulated sufficiently serious practice to overcome the crisis situation and introduce programs of stabilization, which is appropriate in one way or another to integrate into the domestic economic system, taking into account national peculiarities.

\section{The concept and objectives of the economic and social systems of society}

The international community is actively seeking new models of interaction, balance, economic success, social development and political system ${ }^{1}$. The most radical transformations in different spheres of life have coincided in time. The foundations of the future structure are being laid. At the same time, ensuring the long-term competitiveness of the national development project provides that each country must carefully coordinate foreign economic activity with the degree of maturity of internal reforms ${ }^{2}$. Without radical modernization of society, and especially of economic relations, the country will be under threat ${ }^{3}$. The study of the economic and social components of the modern social structure is conditioned by the inadequate practice of their implementation. Today, both the international community and Ukrainian society are actively seeking and

\footnotetext{
${ }^{1}$ Double Shift, Silverman B., Vogt R., Yanowitch M. Transforming Work in Postsocialist and Postindustrial Societies. New York, Los Angeles : M.E. Sharpe, Inc., 1993. 217 p.

Lansbury R.D. Perspectives of Industrial Relations in the Twenty-First Century. The Perspectives of Industrial Relations in the 21st Century. 3rd Asian Regional Congress. Vol. 4. 1997. P. 3-17.

2 Шедяков B.C. Конкурентоспроможність національного проекту економічного розвитку в інформаційну епоху. Формування ринкових відносин в Украӥні. 2005. № 10 (53). С. 17.

3 Лич В.М., Шедяков В.С. Удосконалення методології дослідження системи економічних відносин у процесі модернізації суспільства. Формування ринкових відносин в Україні. 2012. № 9. С. 3.
} 
modernizing more effective models of social and economic systems in order to create an economic balance of social development.

In the present circumstances, one should not focus on universal models and simple solutions to complex problems. Under conditions of globalization, it is not often regional proximity, but national and cultural peculiarities in the balance of economic freedom and state regulation that become factors that largely determine competitiveness. In addition, the routes and forms of ensuring this success can be very diverse and quite distinctive. The study and analysis of the logic of appearance, the idea of a particular institution or mechanism, rather than the automatic borrowing of a successful scheme in a particular environment, is effective $\mathrm{e}^{4}$.

At the same time, political and economic decisions taken in one country can directly influence the formation of public policy in another one. The result of such contradictory tendencies is the increase of new risks that can become a restraining factor in stabilizing the countries macroeconomic environment, building up modern market and non-market institutions, and improving the wellbeing of citizens of the country ${ }^{5}$. Therefore, consideration of the social and economic systems of society as components of the modern social system requires the study of the chosen problem in the light of globalization and European integration processes.

Comprehensive study of the social and economic systems of society requires the disclosure of their content primarily at the categorical rather than everyday level.

Fundamental theoretical and practical contribution to the development of the social system was carried out in his time by B. Havrylyshyn. The scientist considered the economic system as an element in the architecture of the social structure, which itself is a certain system and includes the relevant elements: values (beliefs that affect relationships between individuals or groups, relations within society), political governance (a set of political institutions and procedures), an economic system (a way of organizing the production and distribution of wealth created in society). Values, in his opinion, can be individualist-competitive, group-cooperative, egalitarian-collectivist. The values of society and the forms of political rule determine the main prototypes of economic systems, the scientist identified three of them: the economic system of free enterprise (there prevails the private property, free market, the desire to maximize profits - all that is approved by legislative acts and creates a rival

\footnotetext{
4 Там само.

Чепік-Трегубенко О.С. Теоретико-правові проблеми становлення відкритого суспільства в Україні в умовах глобалізації. Форум права. 2014. № 3. С. 417-422.

${ }^{5}$ Юрчишин В. Стабілізаційна економічна політика в Україні в епоху глобалізації : дис. ... д-ра наук 3 держ. упр. Київ, 2003. С. 17.
} 
relationship between the government, entrepreneurs, employees), the economic system of a co-ordinated free enterprise (similar to the previous one, but with the possibility to reach agreement on national priorities, co-ordination of the government, entrepreneurs, and employees' economic efforts to make it more efficient and more humane), the administrative-command economic system (characterized by state or collective ownership, maximization of production, a totally disorganized market, the decisive role of the government in addressing economic issues through central planning and administrative allocation of resources) ${ }^{6}$. This classification is based on the characterization of economic systems on five grounds: the main motive or criterion of activity (maximizing profit or production, viability), the nature of ownership (private, state, collective), the nature of the market (free, regulated, controlled), the role of the state in the economic system, the root cause and the main goal (economic, social, political) ${ }^{7}$. The proposed authors' vision of the economic system of society as a component of the social structure does not lose its relevance to the international community as a whole and Ukrainian society in particular to this day.

In modern conditions of economic development, the formulation of theoretical positions is directed at understanding the conceptual categorical apparatus not from the standpoint of abstract static, but of dynamism. Such a necessity is due to a rapid change in the development of socio-economic processes, and, accordingly, the priority components of socio-economic integrity; change in quantitative and qualitative parametres in the structure of the components of socio-economic integrity; change of the "integrity of the essence; the dynamic development of scientific ideas in almost all branches of the economy; dynamic development of various organizational forms of cooperative, corporate, associative, integration, functional-cluster, program-target direction; a non-synchronous approach to the development of a structural, functional, hierarchical concept of systems, which violates the harmony in the object of research as a system integrity, etc. ${ }^{8}$

We emphasize that any study is based, first of all, on the refinement of the main categories used in scientific work. Therefore, the study of the question of

\footnotetext{
${ }^{6}$ Грабинський І.М. Сучасні економічні системи : тексти лекцій. Львів : ЛДУ, 1996. С. 21-29.

${ }^{7}$ Гаврилишин Б.Д. До ефективних суспільств: Дороговкази в майбутнє: доп. Рим. Клубові / упоряд. В. Рубцов. 4-те укр. вид., без змін. Київ : Пульсари, 2013. 246 с.

Гаврилишин Б. До ефективних суспільств: доповідь Римському Клубов. 3-тє укр. доп. вид. Київ : Пульсари, 2009. 248 с.

8 Гудзинський О.Д., Судомир С.М. Розвиток соціально-економічних систем в умовах структурної трансформації економіки України. Збірник наукових праць Таврійського державного агротехнологічного університету. Економічні науки. 2017. № 1-2. С. 25-31; Судомир С.М. Формування системи управління розвитком сільськогосподарських підприємств: теорія, методологія : монографія. Київ : Компринт, 2015. $483 \mathrm{c}$.
} 
the development of social and economic systems of society as elements of the modern social structure requires their terminological concretization. This issue is even more actualized in connection with the different theoretical constructs used by scientists in their research. In particular, some scientists believe that it is expedient and methodologically correct to use the terms economic system of society and social system of society separately, while others are proponents of the theory of the term socio-economic system of society. A detailed review of author's approaches to this issue is necessary.

Speaking as a supporter of the use of the concept of socio-economic system, K. Moiseienko substantiates his position as follows: the social nature of the coexistence of people in the course of meeting their needs and its creation morality, law, and so on - determines the unity of social and economic aspects in the economic system, therefore and the need to use the concept of socioeconomic system more objectively refers to a set of relationships between people for the realization of their interests to meet the needs ${ }^{9}$. We believe that such an author's position is not an objective justification of the expediency of combining these phenomena into a single system, yet despite their meaningful proximity. These systems are more likely to be complementary; they still require independent elements of the modern social structure.

In the economic, political, legal, and other literature, a number of definitions of the notion economic system of society are formulated:

a set of interconnected and properly organized productive forces, economic relations and a mechanism of management, the main function of which is to ensure the dynamic balance in social production, first of all, between consumption and production, demand and supply ${ }^{10}$;

1) the sphere of human life, where industrial relations are realized regarding the appropriation, production, distribution, exchange, consumption and regulation of these processes; 2) a set of subsystems (elements) of production, market, prices, money, credit, finance, consumption and connections between them, mediated by the regulatory system, which are characterized by signs of organized nature; presence of integrative properties; institutions and functions (such as the commodity-money character of functioning, the market mechanism, the desire to make a profit); self-regulation aimed at balancing and functioning; 3 ) a set of mechanisms, institutions of functioning, development and regulation of the national economy, which includes the institution of property; institute of production; institute and mechanism of the market, through which the development of production and consumption takes place; price mechanism;

\footnotetext{
${ }^{9}$ Мойсеєнко К.С. Механізм функціонування і розвитку соціально-економічної системи суспільства : дис. .... канд. екон. наук. Чернівці, 2015. С. 33.

10 Экономическая теория: политэкономия : учебник / В.Д. Базилевич, Е.С. Базилевич, Н.И. Гражевская; под ред. В.Д. Базилевича. Москва : Рыбари; Киев : Знання, 2009. С. 119.
} 
mechanism of money; the mechanism of finance, the mechanism of consumption and the mechanism of regulation ${ }^{11}$;

a concrete historical model of the socio-economic mode of production that represents the unity of productive forces and industrial relations under the influence of factors of the superstructure (economic structures and their relations, level of coordination and production management, national customs, cultural traditions, etc. $)^{12}$;

a set of all economic processes that take place in a society based on the relations of ownership and organizational and legal forms in $\mathrm{it}^{13}$;

a set of political, social and economic institutions, organizations, laws, norms, rules and beliefs that interact directly or indirectly, affecting consumption, distribution, exchange and production ${ }^{14}$;

a set of various elements and institutions that organize the national economy and streamline the economic life of people, among the most important mechanisms include mechanisms for coordinating the activities of economic entities, the mechanism of distribution and redistribution of the created national product, mechanisms for the realization of property, monetary mechanism, etc. ${ }^{15}$;

the socio-economic system of society is a hierarchical, integrative, open, adaptive, dynamic, fractal, nonlinear, integral set of organized socio-economic relations of people about meeting their needs and ensuring a common existence in conditions of relatively limited resources and certain social space in the labour process or implementation of other forms of motivated individual and social behavior ${ }^{16}$. Taking into account existing interpretations of the concepts of the economic system of society and the social system of society, modern democratic processes and globalization peculiarities, it is appropriate to define these concepts as follows.

The economic system of society is a coherent, normative and institutionalized interaction of various elements of economic activity aimed at the production, distribution, exchange and consumption of tangible and intangible goods, services, profit making in order to meet the needs and interests of people.

\footnotetext{
11 Башнянин Г.I., Копич I.M., Шевчик Б.М. Економічні системи: проблеми структуризації i типологізації. Львів : Коопосвіта, 1999. С. 39.

${ }^{12}$ Павлышенко М. Экономическая система или способ производства? Экономика Украиныл. 2000. № 3. C. 63.

13 Экономика : учебник / Под ред. А.С. Булатова. Москва : Экономистъ, 2008. С. 16.

${ }^{14}$ Pryor F.L. A Guidebook to the Comparative Study of Economic Systems. Englewood Cliffs. New York : Prentice Hall, 1985. P. 29.

15 Інституційні засади формування економічної системи України: теорія і практика / За ред. 3. Ватаманюка. Львів : Новий Світ-2000, 2005. С. 44.

${ }^{16}$ Мойсеєнко К.С. Механізм функціонування і розвитку соціально-економічної системи суспільства : дис. ... канд. екон. наук. Чернівці, 2015. С. 34.
} 
The social system of society is defined as a coherent, complex and orderly interaction of social associations and individual entities of a general and specific nature.

\section{Directions of development of economic and social systems of society as elements of the social structure}

To achieve the goals it is important to form an adequate target orientation model of the development of society, the economy as a whole and its branches, regions, enterprises as the basic basis for the formation of a management system for the development of socio-economic systems. In modern science, there are several basic models of economic development associated with economic growth: 1) model of linear stages of development (growth); 2) the theory of structural transformations; 3) the theory of external dependence; 4) model of innovation development; 5) the neoclassical model of the free market; 6) the theory of endogenous growth; 7) sustainable development model ${ }^{17}$. In the current conditions of development of the national and world economy, the whole system of relations of organizational, economic, communication, social and other direction becomes complicated. There are problems of organizational interaction of all components of the market competitive environment in conditions of rapidly changing parametres of achievement of goals. In the process of achieving goals there is an imbalance in the system of organizational interaction between management and self-organizing processes. This manifests itself at different levels of management. Violation of the relationship between the state and private property contributed to the imbalance through the weakening of the mechanisms for ensuring unity of interests and the nonwillingness of most of society to work in new non-civilized capitalist conditions of management ${ }^{18}$.

It should be noted, that for a long time the main forms of ownership were state (nationwide), collective-cooperative, as well as property of trade unions and other public organizations. Therefore, the ownership of the means of production in the form of the state (national) and collective-cooperative was the basis of the economic system of the former USSR and the Ukrainian SSR, and all individual property was considered, paradoxically, derived from the main forms of property, that is, a secondary form of ownership. In addition, it should be noted that economic activity was predominantly social in nature, and the

\footnotetext{
17 Система менеджменту інституціональної трансформації економіки України (теоретикометодологічний аспект) : колективна монографія / О.Д. Гудзинський, С.М. Судомир, Ю.С. Гудзинська та інші; за заг. ред. О.Д. Гудзинського Київ : Аграр Медіа Груп, 2012. 771 с.

18 Гудзинський О.Д., Судомир С.М. Розвиток соціально-економічних систем в умовах структурної трансформації економіки України. Збірник наукових праць Таврійського державного агротехнологічного університету. Економічні науки. 2017. № 1-2. С. 25-31.
} 
most complete satisfaction of the growing material and spiritual goods of people was formally considered the highest goal of social production ${ }^{19}$. In contrast to the aforementioned, today according to the provisions of the Constitution of Ukraine, the property of the Ukrainian people is a priority form of ownership. In particular, Article 13 of the Constitution of Ukraine states that the land, its subsoil, atmospheric air, water and other natural resources located within the territory of Ukraine, the natural resources of its continental shelf, and the exclusive (marine) economic zone are objects of the property rights of the Ukrainian people. On their behalf, the right of the owner is exercised by the state authorities and local self-government bodies within the limits established by the current Constitution of Ukraine (Article 13) ${ }^{20}$. Ownership is one of the main components of the formation and functioning of any society and state.

At the current stage, the active involvement of civil society institutions in improving the functioning of the social and political systems of society is important.

Thus, in Ukraine, taking into account the experience of public self-organization in the last year, sufficient prerequisites have been formed to attract civil society resource potential to the process of guaranteeing social security, in particular a wide network of civil society institutions (associations of citizens, volunteer movements), which include, for example, highly skilled specialists in those or other industries. The support of the public sector by businesses and citizens is also growing $^{21}$. Participation and interaction of the society with public authorities has a positive effect on the development of social and economic spheres.

However, positive changes in the creation of legal conditions for the development of civil society in the investigated context are accompanied by significant disadvantages, including the lack of participation of public associations in the formation, adoption and control of the implementation of state policy, the adoption of strategic and ongoing management decisions; undeveloped and ineffective forms of cooperation between public authorities and public associations; an imperfect form of reporting of state authorities, in connection with which there is no information on the inclusion and rejection of public offers on the effectiveness of public assessments, monitoring of public opinion; the lack of integrity of the subject of public consultations on issues of particular importance to society and the state; extremely low activity and

\footnotetext{
${ }^{19}$ Прієшкіна О. Конституційний лад та економічна система: загальнотеоретичні аспекти. Юридичний вісник. 2015. № 1. С. 23.

${ }^{20}$ Конституція України від 28 червня 1996 року. Відомості Верховної Ради України. 1996. № 30. Ст. 141 (зі змінами, внесеними Законом України «Про внесення змін до Конституції України (щодо правосуддя)» від 02 червня 2016 р. Відомості Верховної Ради Украӥни. 2016. № 28. Ст. 532).

21 Соціально-економічний потенціал сталого розвитку України та ії регіонів: вектори реального поступу: національна доповідь. / За ред. Е.М. Лібанової, М.А. Хвесика. Київ : ДУІЕПСР НАН України, 2017. C. 392-393.
} 
initiative of civil society institutions in organizing and conducting consultations with state authorities; lack of skills and knowledge of conducting public expert examination of civil society representatives; groundlessness and low quality of the proposals of civil society institutions in determining the positions, needs, interests in most management decisions; the use of civil society institutions by public authorities for formal representation only at the stage of consultation; defending by the civil society institutions of a narrow range of issues that are limited to group interests, and not socially significant problems, etc. ${ }^{22}$. Unfortunately, the listed problems can be expanded, which indicates the need for more active cooperation on the basis of mutual understanding in order to achieve positive results in the development of the modern social system in general and social and economic spheres in particular.

At present, a separate, fundamental component of the economic and social systems of society as elements of the modern social structure is the formation of socially-oriented business.

The formation of a market economy must be correlated with the real political, spiritual, cultural, psychological, social and economic conditions prevailing in the country, on the basis of which only it is possible to adapt one or another general theoretical model to real socio-economic activity ${ }^{23}$.

Only within a dynamic civil society business as a social institution acquires the degree of freedom that most fully satisfies the economic, socio-cultural and political needs of entrepreneurs in realizing business potential in the direction of developing effective and mutually beneficial socio-economic relations. Being one of the main subsystems of society business is understood as a specific institutional complex for each community. One of the basic factors behind business genesis is the ownership system. Today, civil society emancipates Ukrainian business and removes its dependence on non-governmental institutions and groups of influence, provides consolidation and stability of civil society, minimizes social risks and shocks in the future and promotes prestige of business as a socially significant component of the present ${ }^{24}$. Support and development of business in Ukraine is the basis of its further development, as it will contribute to the improvement of the economic situation of citizens. It is

\footnotetext{
22 Соціальний потенціал сталого розвитку: інноваційні механізми формування та використання : монографія. / О.І. Амоша, О.Ф. Новікова, Ю.С. Залознова та ін. Донецьк, 2014. С. 90-91.

Соціально-економічний потенціал сталого розвитку України та іï регіонів: вектори реального поступу: національна доповідь. / За ред. Е.М. Лібанової, М.А. Хвесика. Київ : ДУІЕПСР НАН України, 2017.864 c.

${ }^{23}$ Иохин В.Я. Экономическая теория : учебник. Москва : Юристъ, 2006. С. 94.

Экономическая теория: политэкономия : учебник / В.Д. Базилевич, Е.С. Базилевич, Н.И. Гражевская; под ред. В.Д. Базилевича. Москва : Рыбари; Киев : Знання, 2009. С. 744.

24 Сфіменко С.А. Соціально-філософські основи бізнесу у контексті сучасного громадянського суспільства : дис. .... канд. філос. наук. Одеса, 2016. С. 14.
} 
also important that the protection of business in our state is a guarantee of attracting foreign investments to Ukraine.

In the conditions of the development of the information society, the issue of establishing an e-economy and e-business as an integral part of it becomes more and more relevant. E-business is aimed first of all at objectively meeting the interests and needs of the public.

Electronic economy is an economic activity based on information technologies, one aspect of which is the management of e-business (online business), electronic money, e-commerce, e-bank, etc. ${ }^{25}$. At the present stage, electronic business models penetrate into all spheres of human life, thus changing the conditions for the development of citizens, societies, as well as interstate associations in general. The electronic business is a theoretical, methodological and practical-applied form of an adequate response of the modern world to the corresponding post-industrial challenges $^{26}$. However, today in Ukrainian legal science issues of legal regulation of e-business in Ukraine are considered rather superficially. As a rule, conceptual developments regarding e-business are presented in economic science, science of public administration, etc.

With the help of the Internet it is possible to quickly and with little expense withdraw and promote products to national and international markets. Internet shops in Ukraine are at the stage of rapid development, since Internet commerce can significantly reduce the cost of products, as there is no need to maintain retail space, it is not necessary to keep sales $\operatorname{staff}^{27}$. The expansion of electronic forms of business is the result of the socio-economic transformation of the conditions of the development and functioning of a modern post-industrial society, resulting in a radical shift of the market towards intangible assets (information, knowledge, intellectual property, rights and obligations, electronic services, software ${ }^{28}$. The further development of the information society on domestic spaces, the introduction and development of modern information and communication technologies will enable the effective formation of the national model of electronic business, taking into account the existing positive experience of other countries in this area.

In this context, it is important to focus attention on the fact that, since the issues of economic development, granting of appropriate permits, etc. are at the disposal of public authorities, the integration and systematic updating of

\footnotetext{
${ }^{25}$ Єфремова К.В. Державна політика та електронний бізнес в Україні. Право та інноваиії. 2015. № 1. C. 50 .

${ }^{26}$ Воробйова О.П. Впровадження електронного бізнесу в Україні: державно-управлінський аспект : автореф. дис. ... канд. наук з держ. упр. Київ, 2013. С. 2.

${ }_{27}$ Ситник І.П., Головіна А.В. Електронний бізнес і його розвиток в Україні. Молодий вчений. 2016. № 2. C. 79.

${ }^{28}$ Воробйова О.П. Впровадження електронного бізнесу в Україні: державно-управлінський аспект : автореф. дис. ... канд. наук з держ. упр. Київ, 2013. С. 9.
} 
information and communication technologies in the work of public authorities and local self-government bodies is among the top priorities.

State policy in the field of electronic business at this stage of its historical development is fragmentary with a priority orientation on the issue of the introduction of e-governance without a clear understanding of the difference between it and e-business, as previously noted by the author. However, it is impossible to underestimate the existing attempts to implement e-governance, as this is virtually the basis for the establishment of e-business in the future ${ }^{29}$. In addition, electronic business as a new bureaucratic paradigm of public administration, which is a logical historical prospect of state development in the context of the information age, provides for the creation of a more flexible and efficient market-oriented system of public administration aimed at the clientcitizen. This paradigm necessitates the introduction of new institutions and mechanisms in the practice of management, reviewing decision-making procedures in order to increase their efficiency and effectiveness ${ }^{30}$. The formation of e-business will accelerate the pace of development of the economic and social systems of society through the development of small and mediumsized businesses. The joint work of the public, parliamentarians, academics, business people and others in this direction is now needed in order to improve the existing legal framework and develop new legislative projects. The priority issues that require a legal settlement are the protection of consumers' rights using e-commerce services, legal protection of ICS and copyrights on the Internet, problem aspects of advertising, protection of personal data, etc. The specified will also be a prerequisite for improving the innovation and investment climate in Ukraine.

Considering a qualitatively new role of the economic system of society as an important element for building a modern social structure, we must realize that we are approaching fundamentally new forms of relations in which the approach to further use of property (the basis of the modern economic system) will be determined not by the status of individuals, but by the purpose for satisfaction of social needs.

New horizons of development are open to those states, where the social structure optimally promotes the realization of creative potential of citizens. Ensuring a decent place in the global coordinate system involves transforming the state into a truly innovative one, along with the bureaucracy reduction, increase in creative functions and the construction of a mechanism for virtually

\footnotetext{
${ }^{29}$ Єфремова К.В. Державна політика та електронний бізнес в Україні. Право та інновації. 2015. № 1. C. 52 .

${ }^{30}$ Воробйова О.П. Впровадження електронного бізнесу в Україні: державно-управлінський аспект : автореф. дис. ... канд. наук з держ. упр. Київ, 2013. С. 11.
} 
continuous participation of citizens in a social organization ${ }^{31}$. Therefore, today human creativity in any sphere is an important component of the development of the social structure and its components, such as social and economic systems.

It is essential that at present the growth of science intensity of all aspects of public life and the development of new technologies, forms of organization of work and ergonomic regimes of labour activity, the spread of the use of the latest achievements of various branches of science in the economy, attention to the analysis of the current state of corporations, the definition of the causes of intellectual, material, commercial losses and the elaboration on this basis of both operational and tactical responses, and strategic objectives of socio-economic development - all this is gaining great importance for increasing the productivity of economic relations and the effectiveness of creative efforts of specialists $^{32}$.

Information and communication technologies have become the basis for the formation of a new type of economy - cybereconomy, due to the provision of unique opportunities in the field of the movement of capital, goods and services. Therefore, the modern economic system of the Ukrainian society in particular is forced to adapt to information and computer reality. World trends make it necessary to carry out an innovation and structural restructuring of the domestic economic system of society, since today the lack of the specified significantly weakens the position of Ukraine and suspends its integration. The analysis of this problem requires the statement: the development of the spiritual, cultural and political spheres today increasingly faces the problem of the delay in the formation of an open economic system.

An open society is characterized by a large number of signs, but as regards the most advanced modern economic system in the system of protecting the rights of the individual, referring to the International Covenant on Economic, Social and Cultural Rights, this should be a remuneration that would at least provide to all working people: fair wages and equal pay for work of equal value without any difference, in particular, women must be guaranteed working conditions that are no worse than those used by men with equal pay for equal work; satisfactory existence for themselves and their families in accordance with the provisions of this Covenant; conditions of work that meet the requirements of safety and hygiene; the same opportunity for all to move on to the corresponding higher levels solely on the basis of seniority and qualifications;

\footnotetext{
31 Лич В.М., Шедяков В.С. Удосконалення методології дослідження системи економічних відносин у процесі модернізації суспільства. Формування ринкових відносин в Украӥні. 2012. № 9. С. 5.

32 Там само.

Beck U., Giddens A., Lash S. Reflexive Modernization: Politics, Traditions and Aesthetics in the Modern Social Order. Cambridge : Polity Press, 1994. 85 p.
} 
rest, leisure and reasonable limitation of working time and paid periodic holidays as well as remuneration for holidays ${ }^{33}$. The existence of different forms of ownership, security, protection, respect for society and government for private property, and democratic market relations are conditions for the effective functioning of the modern social system of Ukraine.

In a decentralized environment, self-organization of the public seems to be necessary, which will contribute to regional development.

After all, nowadays regional policy is focused not on the development of regions, but on their support, which does not contribute to the socio-economic uplift of the country. Therefore, regions need to make the transition to the formation and implementation of a self-development policy. This is especially important in the context of the limited economic, social, financial and other resources of the state, when the actual task is to introduce mechanisms for the effective use of socio-economic potential of regions on the basis of selfdevelopment ${ }^{34}$. This condition is associated with the lack of elaboration of mechanisms for regional and local self-development.

We emphasize that self-development of the region is a self-sufficient socioeconomic development with adaptive properties for overcoming unfavorable social, economic and ecological tendencies and with the ability of the region to achieve balanced development, self-regulation, self-improvement with maximum use of internal reserves, as well as external borrowing resources to meet the needs of the population ${ }^{35}$. Self-development of the region involves the ability of authorized entities to determine the purpose and objectives correctly, their implementation in accordance with existing realities.

\section{CONCLUSIONS}

Summing up the theoretical and legal analysis of the social and economic systems of society as elements of the modern social structure, it is necessary to note the following.

1. The subject of scientific knowledge of the economic and social systems as elements of the modern social structure of Ukraine has a significant theoretical and applied role and focuses on the political and legal aspects of science in the theory of state and law and branch legal sciences. Knowledge of the economic and social components of the modern social structure is determined by the inadequate practice of their implementation. Today, both the international

\footnotetext{
33 Міжнародний пакт про економічні, соціальні і культурні права від 16 грудня 1966 p. URL: http://zakon4.rada.gov.ua/ laws/show/995_042/card6\#Public.

34 Соціально-економічний потенціал сталого розвитку України та іï регіонів: вектори реального поступу: національна доповідь. / За ред. Е.М. Лібанової, М.А. Хвесика. Київ : ДУІЕПСР НАН України, $2017.864 \mathrm{c}$.

35 там само.
} 
community and Ukrainian society are actively seeking and modernizing more effective models of social and economic systems in order to create an economic balance of social development. The existence of different forms of ownership, security, protection, societies and governments respect for private property, and democratic market relations are conditions for the effective functioning of the modern social system of Ukraine. World trends make it necessary to carry out an innovation and structural restructuring of the domestic economic system of society, since today the lack of the specified significantly weakens the position of Ukraine and suspends its integration. The analysis of this problem requires the statement: the development of the spiritual, cultural and political spheres today increasingly faces the problem of the delay in the formation of an open economic system.

2. Modern economic and social systems of society are complex entities. The economic system of society is a coherent, normative and institutionalized arrangement of the interaction of various elements of economic activity aimed at the production, distribution, exchange and consumption of tangible and intangible goods, services, profit making in order to meet the needs and interests of people. The social system of society is defined as a coherent, complex and orderly interaction of social associations and individual entities of a general and specific nature.

3. Ensuring the citizens of Ukraine with the opportunity to fully implement economic and social rights requires the renewal of the economic system of society in the following areas: active introduction of innovative technologies; cooperation and attraction of international investors; promotion of the peoples creative potential; maximum supply of goods by the national market; transition to a system of export of end-use goods, not raw materials; balance of economic freedom; providing high-quality service. Their implementation requires the reform of domestic legislation, the detailed elaboration of a national mechanism for achieving this, with the involvement of representatives of Ukrainian and foreign business.

4. Information and communication technologies have become the basis for the formation of a new type of economy - cybereconomy, due to the provision of unique opportunities in the field of the movement of capital, goods and services. The modern economic system of Ukrainian society is forced to adapt to information and computer reality. World trends make it necessary to carry out an innovation restructuring of the domestic economic system of society, since today the absence of the specified significantly weakens the position of Ukraine and suspends its integration. 


\section{SUMMARY}

The paper reveals the problems of the development of the economic and social systems of society as elements of the social structure from the standpoint of the science of the theory of state and law. It is stressed that today, both the international community and Ukrainian society are actively seeking and modernizing more effective models of social and economic development. It is emphasized that the latest trends make it possible to carry out an innovation restructuring of the domestic economic system of society, since today the lack of the specified significantly weakens the position of Ukraine and suspends its integration. It is concluded that the development of spiritual, cultural and political spheres today increasingly faces the problem of the delay in the formation of an open economic system. It is highlighted that modern economic and social systems of society are complex formations; the definition of concepts "economic system of society" and "social system of society" are formulated. The directions of the modernization of the economic system of the society, which will help ensure the citizens of Ukraine with the opportunity to fully implement economic and social rights, are determined.

\section{REFERENCES}

1. Double Shift, Silverman B., Vogt R., Yanowitch M. Transforming Work in Postsocialist and Postindustrial Societies. New York, Los Angeles : M.E. Sharpe, Inc., 1993. 217 p.

2. Lansbury R.D. Perspectives of Industrial Relations in the Twenty First Century. The Perspectives of Industrial Relations in the 21st Century. 3rd Asian Regional Congress. Vol. 4. 1997. P. 3-17.

3. Шедяков В.С. Конкурентоспроможність національного проекту економічного розвитку в інформаційну епоху. Формування ринкових відносин в Україні. 2005. № 10 (53). С. 16-22.

4. Лич В.М., Шедяков В.С. Удосконалення методології дослідження системи економічних відносин у процесі модернізації суспільства. Формування ринкових відносин в Україні. 2012. № 9. С. 3-7.

5. Юрчишин В. Стабілізаційна економічна політика в Україні в епоху глобалізації : дис. ... д-ра наук з держ. упр. Київ, 2003. 400 с.

6. Грабинський I.M. Сучасні економічні системи : тексти лекцій. Львів : ЛДУ, 1996. 176 с.

7. Гаврилишин Б.Д. До ефективних суспільств: Дороговкази в майбутнє: доп. Рим. Клубові / упоряд. В. Рубцов. 4-те укр. вид., без змін. Київ : Пульсари, 2013. 246 с.

8. Гаврилишин Б. До ефективних суспільств: доповідь Римському Клубов. 3-тє укр. доп. вид. Київ : Пульсари, 2009. 248 с. 
9. Гудзинський О.Д., Судомир С.М. Розвиток соціально-економічних систем в умовах структурної трансформації економіки України. Збірник наукових праць Таврійського державного агротехнологічного університету. Економічні науки. 2017. № 1-2. С. 25-31.

10. Судомир С.M. Формування системи управління розвитком сільськогосподарських підприємств: теорія, методологія : монографія. Київ : Компринт, 2015. 483 с.

11. Мойсеєнко К.Є. Механізм функціонування і розвитку соціальноекономічної системи суспільства : дис. ... канд. екон. наук. Чернівці, 2015. $229 \mathrm{c}$.

12. Экономическая теория: политэкономия : учебник / В.Д. Базилевич, Е.С. Базилевич, Н.И. Гражевская; под ред. В.Д. Базилевича. Москва : Рыбари; Киев : Знання, 2009. 870 с.

13. Башнянин Г.I., Копич I.М., Шевчик Б.М. Економічні системи: проблеми структуризації і типологізації. Львів : Коопосвіта, 1999. 220 с.

14. Павлышенко М. Экономическая система или способ производства? Экономика Украины. 2000. № 3. С. 63-72.

15. Pryor F.L. A Guidebook to the Comparative Study of Economic Systems. Englewood Cliffs. New York : Prentice Hall, 1985. 342 p.

16. Экономика : учебник / Под ред. А.С. Булатова. Москва : Экономистъ, 2008. $831 \mathrm{c}$.

17. Чепік-Трегубенко О.С. Теоретико-правові проблеми становлення відкритого суспільства в Україні в умовах глобалізації. Форум права. 2014. № 3. C. 417-422.

18. Система менеджменту інституціональної трансформації економіки України (теоретико-методологічний аспект) : колективна монографія / О.Д. Гудзинський, С.М. Судомир, Ю.С. Гудзинська та інші; за заг. ред. О.Д. Гудзинського. Київ : Аграр Медіа Груп, 2012. 771 с.

19. Прієшкіна О. Конституційний лад та економічна система: загальнотеоретичні аспекти. Юридичний вісник. 2015. № 1. С. 23-30.

20. Конституція України від 28 червня 1996 року. Відомості Верховної Ради України. 1996. № 30. Ст. 141 (зі змінами, внесеними Законом України «Про внесення змін до Конституції України (щодо правосуддя)» від 02 червня 2016 р. Відомості Верховної Ради Украӥни. 2016. № 28. Ст. 532).

21. Соціально-економічний потенціал сталого розвитку України та іï регіонів: вектори реального поступу: національна доповідь. / За ред. Е.М. Лібанової, М.А. Хвесика. Київ : ДУІЕПСР НАН України, 2017. 864 с.

22. Соціальний потенціал сталого розвитку: інноваційні механізми формування та використання : монографія. О.І. Амоша, О.Ф. Новікова, Ю.С. Залознова та ін. Донецьк, 2014. 478 с. 
23. Иохин В.Я. Экономическая теория : учебник. Москва : Юристъ, 2006. $681 \mathrm{c}$.

24. Єфіменко С.А. Формування партнерської взаємодії бізнесу та влади у контексті формування підприємництва в Україні. Scientific Journal «ScienceRise». 2015. № 10 (15). C. 52-55.

25. Сфремова К.В. Державна політика та електронний бізнес в Україні. Право та інновачіï. 2015. № 1. С. 50-54.

26. Воробйова О.П. Впровадження електронного бізнесу в Україні: державно-управлінський аспект : автореф. дис. ... канд. наук з держ. упр. Київ, 2013. 20 с.

27. Ситник І.П., Головіна А.В. Електронний бізнес і його розвиток в Україні. Молодий вчений. 2016. № 2. С. 79-82.

28. Лич В.М., Шедяков В.С. Удосконалення методології дослідження системи економічних відносин у процесі модернізації суспільства. Формування ринкових відносин в Україні. 2012. № 9. С. 3-7.

29. Міжнародний пакт про економічні, соціальні і культурні права від 16 грудня 1966 p. URL: http://zakon4.rada.gov.ua/laws/show/995_042/ card6\#Public.

\section{Information about authors:} Nalyvaiko O. I., Candidate of Law, Associate Professor, Research Associate Secretariat of the Academic Council of Dnipropetrovsk State University of Internal Affairs Ave. Gagarina, 26, Dnipro, Ukraine

\section{Chepik-Tregubenko O. S.,}

Candidate of Law, Associate Professor of the Department of General Legal Disciplines of Dnipropetrovsk State University of Internal Affairs Ave. Gagarina, 26, Dnipro, Ukraine 